\title{
Evaluation of Carrot Pomace (Daucus carota L.) as Hypocholesterolemic and Hypolipidemic Agent on Albino Rats
}

\author{
Abd El-Moneim M.R. AFIFY'*, Ramy R.M. ROMEILAH ${ }^{1}$, Mahmoud \\ M.H.OSFOR², AmirS.M.ELBAHNASAWY² \\ ${ }^{1}$ Cairo University, Faculty of Agriculture, Biochemistry Department, P. Box 12613, Gamma \\ Street, Giza,Egypt; Moneimafify@yahoo.com ("correspondingauthor) \\ ${ }^{2}$ National Research Center, Food Science and Nutrition Department, Dokki, Giza, Egypt
}

\begin{abstract}
The current study examined the attenuating influence of dietary carrot pomace powder (CaPP) on hypercholesterolemia and various oxidative stress-associated with biochemical parameters in hypercholesterolemic rats. Thirty two male albino rats weighing $110 \pm 10 \mathrm{~g}$ were divided into four groups, the first group received the basal diet only and served as (negative control), the second group received the hypercholesterolemic diet and served as positive control, the other groups received hypercholesterolemic diet supplemented with 10\%, 20\% CaPP for six weeks. The obtained results revealed that groups supplemented with 10\% and 20\% CaPP significantly decrease total lipid, total cholesterol, triglycerides, low density lipoprotein cholesterol, liver enzymes: alanine aminotransferase, aspartate aminotransferase compared to positive and negative groups. Organs weight, body weight gain significantly decreased compared with positive control. Moreover dietary carrot pomace powder can used to reduce the body weight and reducing hypercholesterolemic complications. In addition, dietary carrot pomace powder serves to improve the blood picture and to reduce the blood glucose level in hypercholesterolemic rats and could use in obese people for body loss. Data of kidney function (Urea) record an increase in CaPP $20 \%$ level (26.9 \pm 2.96$)$ but this increase was non significant with the negative control group $(26.6 \pm 3.1)$.
\end{abstract}

Keywords: Daucus carota, hypercholesterolemia, kidney function, obese people

\section{Introduction}

Although cholesterol is important and necessary for mammals, but high levels of cholesterol in the blood can damage arteries and are potentially linked to diseases such as those associated with the cardiovascular system and heart disease (Ingelsson et al., 2007).

Fiber is often classified according to its solubility in water into soluble and insoluble dietary fibers (Schneeman, 2007; Van Way and Ireton-Jones, 2004). Increased dietary fiber intakes are associated with significantly lower prevalence rates of cardiovascular disease (Graham et al., 2007). Soluble fiber, when included within a low saturated fat and cholesterol diet, lowers low-density lipoprotein cholesterol concentration about 5-10\% in hypercholesterolaemic and diabetic patients (Anderson et al., 2009). A high intake of fiber, particularly of the soluble type, above the level recommended (25-35 g/day) by the American Dietetic Association (ADA), improves glycemic control, decreases hyperinsulinemia, and lowers plasma lipid concentrations (Chandalia et al., 2000).

Waste by-products of vegetable food processing represent a major disposal problem in industry (Schieber et al., 2001). Its transformation into value added products, as fibers may contribute to diminish the problem and to recover valuable biomass and nutrients (Gerschenson $e t$ al., 2009).

Carrot (Daucus carota) is an important root vegetable, and usually used for juice production, and there is a steady increase in carrot juice consumption (Schieber $e t$ al., 2001). In the juice industry, thousands of tons of carrot pomace are produced after the juice extraction. Carrot pomace rich in insoluble fiber-rich fraction $(56.3 \mathrm{~g} / 100 \mathrm{~g}$ of pomace), which was mainly composed of pectic polysaccharides, hemicellulose, and cellulose. This insoluble fiberrich fraction was found to have desirable physicochemical properties such as high water- and oil-holding capacities, cation-exchange capacity, glucose-adsorbing ability, and amylase inhibition activity (Chau et al., 2004a). Carrot pomace has the highest percentage of soluble fiber when compared with apple, cabbage, strawberry, black currant, and chokeberry pomace (Chantaro et al., 2008; Nawirska and Uklańska, 2008).

Chau et al. (2004b) found that the inclusion of pomace fiber in diet effectively decreased the concentrations of serum triacylglycerol, serum total cholesterol, and liver cholesterol, and increased the concentrations of fecal total lipid, fecal cholesterol, and fecal bile acids, and showing 
8

pronounced hypolipidemic and hypocholesterolemic effects.

The objectives of this study are to investigate the hypocholesterolemic effects of carrot pomace powder in albino rats, furthermore explore the possibility of recycling the waste by-product of food processing to produce a high fiber rich product.

\section{Materials and methods}

\section{Materials}

Fresh carrot pomace (Daucus carota) was obtained from local juice extraction shops, and then dried in an airoven at $45^{\circ} \mathrm{C}$ for $48 \mathrm{~h}$. The dried pomace was ground in a Multi Mill apparatus and passed through a $0.5-\mathrm{mm}$ mesh sieve to obtain a fine carrot pomace powder.

\section{Chemical composition}

The determination of moisture, crude protein, total lipid, ash and crude fibers were done, nitrogen free extract was calculated by difference, deducing the percentage of ash, crude protein, total lipid and crude fibers from 100 according to AOAC (2000).

\section{Biological effects of carrot pomace powder}

\section{Experimental animals and diets}

Thirty two Spraque-Dawley male albino rats weighing $110 \pm 10 \mathrm{~g}$ were obtained from the laboratory animal house, National Research Center. The animals were housed individually in stainless steel cages in a controlled environment $\left(25 \pm 2^{\circ} \mathrm{C}, 50-60 \%\right.$ relative humidity and 12 hour light-dark cycle). The animals were fed ad libitum with a basal diet and water for two weeks, and were then randomly assigned to 4 groups ( 8 rats each) as follows:

Group 1 (negative control): received basal diet consisting of starch $65 \%$, casein $10 \%$, corn oil $10 \%$, salt mixture $4 \%$, vitamins mixture $1 \%$ and cellulose $10 \%$ (AOAC, 2000).

Group 2 (positive control): received hypercholesterolemia-induced diet (high fat diet) which prepared as basal diet preparation, except that the $10 \%$ corn oil portion was replaced with $10 \%$ sheep fat and it was supplemented with $1 \%$ cholesterol and $0.25 \%$ bile salts (Fukushima et al., 1997).

Group 3: received $80 \%$ high fat diet plus $20 \%$ carrot pomace powder.

Group 4: received 90\% high fat diet plus 10\% carrot pomace powder.

\section{Experimental design}

During the experimental period ( 6 weeks), water and diets were available ad libitum. At the end of the experiment, all the animals were scarified by cervical decapitation. Blood samples were collected in two tubes. The first one $(0.5 \mathrm{ml}$ blood $)$ was used for the determination of blood hemoglobin, red blood cells (RBCs), white blood cells (WBCs) and hematocrit (HCT), the 2nd heparinized tube was centrifuged at $2500 \mathrm{rpm}$ at $37^{\circ} \mathrm{C}$ for $15 \mathrm{~min}$ to separate the plasma which was kept in the deep freezer for the subsequent investigation. Also, body weight, food consumption were recorded day after day.

\section{Biochemical analysis}

\section{Lipid profile}

Plasma total lipid (TL), triglycerides (TG), total cholesterol (TC), low density lipoprotein cholesterol (LDLC) and high density lipoprotein cholesterol (HDL-C) were determined according to Knight et al. (1972), Fossati and Prencipe (1982), Allain et al. (1974), Levy (1981) and Burstein (1970), respectively. Atherogenic Index (AI) was calculated according to Lee and Niemann (1996) using following equation:

Atherogenic Index $(\mathrm{AI})=\frac{\text { Total Cholesterol }-\mathrm{HDL}-\mathrm{C}}{\mathrm{HDL}-\mathrm{C}}$

Determination of AST, ALT and ALP activities (liver functions)

Aspartate aminotransferase (AST) and alanine aminotransferase (ALT) activities were measured colorimetrically at $340 \mathrm{~nm}$ in plasma according to the method described by Reitman and Frankel (1957). Alkaline phosphatase (ALP) activity in plasma was determined colorimetrically at $405 \mathrm{~nm}$ according to the method of Rec (1972).

\section{Determination of urea and creatinine (kidney functions)}

For kidney functions urea in plasma was determined colorimetrically at $578 \mathrm{~nm}$ according to the methods described by Patton and Crouch (1977) and the determination of plasma creatinine content was carried out colorimetrically at $510 \mathrm{~nm}$ according to the methods described by Faulkner and King (1976).

\section{Determination of glucose}

Plasma glucose level was determined colorimetrically at $510 \mathrm{~nm}$ according to Trinder (1969).

\section{Determination of total protein and albumin}

Plasma total protein and plasma albumin were determined colorimetrically according to the methods described by Henry (1976) and Doumas and Peters (1997) respectively.

\section{Blood picture}

\section{Blood hemoglobin}

The concentration of blood hemoglobin was determined colorimetrically at $546 \mathrm{~nm}$ according to the meth- 
od of International Committee for Standardization in Haematology (1967).

Red blood cells (RBCs) and White blood cells (WBCs):

Red blood cells (RBCs) count and White blood cells (WBCs) count were measured according to the method of Natt and Herrick (1952).

\section{Hematocrit (HCT)}

Hematocrit (HCT) was determined according to the method of Campbell (1995). Hematocrit is the percent volume of whole blood occupied by red blood cells and is determined by centrifuging blood in special (hematocrit) capillary tubes.

\section{Statistical analysis}

Statistical analysis (standard deviation "SD" and standard error "SE") was carried out according to Fisher (1970). LSD (Least significant difference) test was used to compare the significant differences between means of treatment (Waller and Duncan, 1969). The statistical package for social science SPSS (1999) program version was used for all analysis.

\section{Results}

\section{Chemical composition}

The chemical composition of carrot pomace powder was shown in Tab. 1 . The crude fiber content was (11.80\%) dry weight basis, the ash content was $6.24 \%$, crude protein 6.86 while total lipid was $1.48 \%$ dry weight basis.

Tab. 1. Chemical composition of carrot pomace as (g/100 g) dry weight basis

\begin{tabular}{ccccccc}
\hline Sample & $\begin{array}{c}\text { Moisture } \\
\text { (Air dry) }\end{array}$ & $\begin{array}{c}\text { Crude } \\
\text { protein }\end{array}$ & $\begin{array}{c}\text { Total } \\
\text { lipid }\end{array}$ & Ash & $\begin{array}{c}\text { Crude } \\
\text { fiber }\end{array}$ & $\begin{array}{c}\text { Nitrogen } \\
\text { free extract }\end{array}$ \\
\hline $\begin{array}{c}\text { Carrot } \\
\text { pomace }\end{array}$ & 26.5 & 6.86 & 1.48 & 6.24 & 11.80 & 73.62 \\
\hline
\end{tabular}

Moisture of fresh carrot pomace was $86.8 \%$

\section{Biological effects of carrot pomace powder}

Tab. 2 illustrates the body weight gain (BWG), food intake and feed efficiency ratio (FER) at the end of the study. The results showed that the addition of CaPP with $10 \%$ level, decreased (BWG) (1.8 \pm 0.07$)$, while the addition of CaPP with $20 \%$ level was highly significantly decreased $(1.0 \pm 0.07)$ than the positive control $(2.4 \pm 0.06)$.

It was noticed that, there was no significant changes in food intake among carrot pomace at the level of $20 \%$ $(16.8 \pm 0.38), 10 \%(16.7 \pm 0.30)$ and negative control $(18.0 \pm 0.60)$, but there was a significant decrease comparing with the positive control $(20.1 \pm 0.33)$.

Also the feed efficiency ratio (FER) of the $20 \% \mathrm{CaPP}$ group recorded a significant decrease $(0.06 \pm 0.00)$ compared with positive control group $(0.12 \pm 0.00)$ while
Tab. 2. The mean value of Body Weight Gain, Feed Efficiency Ratio and Food Intake in the experimental rats

\begin{tabular}{|c|c|c|c|}
\hline Treatments & $\begin{array}{c}\text { Body weight } \\
\text { gain } \\
\text { g/d }\end{array}$ & FER & $\begin{array}{c}\text { Food intake } \\
\mathrm{g} / \mathrm{d}\end{array}$ \\
\hline $\begin{array}{c}\text { G-1 } \\
\text { Negative Control }\end{array}$ & $1.3 \pm 0.11 \mathrm{c}$ & $0.07 \pm 0.00 \mathrm{~b}$ & $18.0 \pm 0.60 \mathrm{~b}$ \\
\hline $\begin{array}{c}\text { G-2 } \\
\text { Positive Control }\end{array}$ & $2.4 \pm 0.06 \mathrm{a}$ & $0.12 \pm 0.00 \mathrm{a}$ & $20.1 \pm 0.33 \mathrm{a}$ \\
\hline $\begin{array}{c}\text { G-3 } \\
20 \% \text { CaPP }\end{array}$ & $1.0 \pm 0.07 \mathrm{~d}$ & $0.06 \pm 0.00 \mathrm{~b}$ & $16.8 \pm 0.38 \mathrm{~b}$ \\
\hline $\begin{array}{c}\text { G-4 } \\
10 \% \mathrm{CaPP}\end{array}$ & $1.8 \pm 0.07 \mathrm{~b}$ & $0.11 \pm 0.00 \mathrm{a}$ & $16.7 \pm 0.30 \mathrm{~b}$ \\
\hline
\end{tabular}

All values represented as mean \pm S.E. Means with different letters are significantly different $(p<0.05) .{ }^{*} \mathrm{CaPP}$ (carrot pomace powder)

there were no significant changes in $10 \% \mathrm{CaPP}$ group $(0.11 \pm 0.00)$.

On other hand 20\% CaPP group showed FER value around the negative control $(0.06 \pm 0.00$ and $0.07 \pm 0.00)$ respectively.

Rats fed on hypercholesterolemia-induced diet developed hypercholesterolemia mark by significant increase in plasma total lipid, triglycerides, total cholesterol, low density lipoprotein cholesterol (LDL-C), and atherogenic Index (AI) compared with negative control rats, while high density lipoprotein cholesterol (HDL-C) showed significant decrease (Tab. 3).

It is obvious that the intake of $\mathrm{CaPP}$ with different concentrations significantly alleviated the total lipid compared with positive control (1252 \pm 36.5$)$, but with no significant changes between them (10\% and 20\%), (609 \pm 19.8$)$ and $(569 \pm 22)$ respectively.

Total cholesterol recorded high significant decrease in the different concentration of CaPP $(10 \%$ and $20 \%)$ $(193 \pm 4.15)$ and $(183 \pm 4.3)$ respectively compared with the positive control group $(388.9 \pm 11.8)$ while there were non significant changes with the negative control group

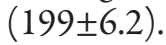

It can be noticed that the intake of CaPP with level $20 \%$ recorded some decrease in the total cholesterol than group with $10 \%$ and the negative group. In the same table, the triglycerides showed high significant decrease in group $3(88.9 \pm 3.6)$ and group $4(109 \pm 3.53)$ compared with the positive control (395 \pm 17.2$)$, but the decrease in triglycerides of group 3 was non significant as compared with the negative control group (124 \pm 7.6 ).

Data in Tab. 3 demonstrates that the increase in LDL$\mathrm{C}$ was improved by supplementation with $\mathrm{CaPP}$ with different concentrations to hypercholesterolemic rats. The highest decrease in LDL-C was observed in group fed with $20 \% \mathrm{CaPP}(114 \pm 4.05)$ compared with positive control $(324 \pm 11.5)$ and negative control $(140 \pm 3.4)$, while the $10 \%$ level of CaPP $(121 \pm 3.92)$ was non significant compared to negative control. 
10

Tab. 3. Plasma total lipid, total cholesterol, triglycerides, LDL-C, HDL-C (mg/dl) and AI in the experimental rats

\begin{tabular}{|c|c|c|c|c|c|c|}
\hline Treatments & $\begin{array}{l}\text { Total lipid } \\
(\mathrm{mg} / \mathrm{dL})\end{array}$ & $\begin{array}{l}\text { Total cholesterol } \\
(\mathrm{mg} / \mathrm{dl})\end{array}$ & $\begin{array}{l}\text { Triglycerides } \\
(\mathrm{mg} / \mathrm{dL})\end{array}$ & $\begin{array}{l}\text { LDL-C } \\
(\mathrm{mg} / \mathrm{dl})\end{array}$ & $\begin{array}{l}\text { HDL-C } \\
(\mathrm{mg} / \mathrm{dl})\end{array}$ & $\mathrm{AI}$ \\
\hline $\begin{array}{c}\text { G-1 } \\
\text { Negative Control }\end{array}$ & $631 \pm 38.1 \mathrm{~b}$ & $199 \pm 6.2 \mathrm{~b}$ & $124 \pm 7.6 \mathrm{~b}$ & $140 \pm 3.4 \mathrm{~b}$ & $48.4 \pm 3.0 \mathrm{a}$ & 3.11 \\
\hline $\begin{array}{c}\text { G-2 } \\
\text { Positive Control }\end{array}$ & $1252 \pm 36.5 \mathrm{a}$ & $388.9 \pm 11.8 \mathrm{a}$ & $395 \pm 17.2 \mathrm{a}$ & $324 \pm 11.5 \mathrm{a}$ & $37.8 \pm 3.5 \mathrm{~b}$ & 9.28 \\
\hline $\begin{array}{c}\text { G-3 } \\
20 \% \text { CaPP }\end{array}$ & $569 \pm 22 \mathrm{~b}$ & $183 \pm 4.3 \mathrm{~b}$ & $88.9 \pm 3.6 \mathrm{c}$ & $114 \pm 4.05 \mathrm{c}$ & $51.5 \pm 2.44 \mathrm{a}$ & 2.55 \\
\hline $\begin{array}{c}\text { G-4 } \\
10 \% \mathrm{CaPP}\end{array}$ & $609 \pm 19.8 \mathrm{~b}$ & $193 \pm 4.15 b$ & $109 \pm 3.53 \mathrm{bc}$ & $121 \pm 3.92 b c$ & $47.1 \pm 2.36 \mathrm{a}$ & 3.10 \\
\hline
\end{tabular}

All values represented as mean + S.E. Means with different letters are significantly different $(p<0.05) .{ }^{*} \mathrm{CaPP}($ carrot pomace powder $)$

Tab. 4. Complete blood picture of the experimental rats

\begin{tabular}{|c|c|c|c|c|}
\hline Parameters & $\begin{array}{l}\text { Hemoglobin } \\
\qquad(\mathrm{g} / \mathrm{dL})\end{array}$ & $\begin{array}{c}\text { RBCs Count } \\
\left(\times \text { million cells } / \mathrm{mm}^{3}\right)\end{array}$ & $\begin{array}{c}\text { Hematocrit Value } \\
\text { (HCT \%) }\end{array}$ & $\begin{array}{l}\text { WBCs Count } \\
\left(\times 10^{3} \text { cells } / \mu \mathrm{L}\right)\end{array}$ \\
\hline $\begin{array}{c}\text { G-1 } \\
\text { Negative Control }\end{array}$ & $11.2 \pm 0.55 b$ & $5.2 \pm 0.17 \mathrm{a}$ & $36.9 \pm 2.02 \mathrm{a}$ & $9.6 \pm 0.84 \mathrm{a}$ \\
\hline $\begin{array}{c}\text { G-2 } \\
\text { Positive Control }\end{array}$ & $9.3 \pm 0.55 \mathrm{c}$ & $3.6 \pm 0.18 \mathrm{~b}$ & $29.1 \pm 1.03 \mathrm{~b}$ & $3.3 \pm 0.24 \mathrm{c}$ \\
\hline $\begin{array}{c}\text { G-3 } \\
20 \% \text { CaPP }\end{array}$ & $12.8 \pm 0.42 \mathrm{a}$ & $5.1 \pm 0.15 \mathrm{a}$ & $39.4 \pm 1.36 \mathrm{a}$ & $7.1 \pm 1.42 \mathrm{ab}$ \\
\hline $\begin{array}{c}\text { G-4 } \\
10 \% \mathrm{CaPP}\end{array}$ & $11.8 \pm 0.4 \mathrm{ab}$ & $4.7 \pm 0.16 \mathrm{a}$ & $35.5 \pm 1.39 \mathrm{a}$ & $4.9 \pm 0.99 \mathrm{bc}$ \\
\hline
\end{tabular}

All values represented as mean + S.E. Means with different letters are significantly different $(p<0.05) .{ }^{*} \mathrm{CaPP}$ (carrot pomace powder)

The HDL-C in the pervious table recorded a high significant increase in group 3 and 4 compared with the positive control (37.8 \pm 3.5$)$. It can be noticed that the intake of $\mathrm{CaPP}$ with level $20 \%$ recorded highly increase in HDL-C $(51.5 \pm 2.44)$ but this increase was non significant compared with negative control and the 10\% CaPP $(48.4 \pm 3.0$ and $47.1 \pm 2.36)$ respectively. Supplementation with $20 \%$ and $10 \% \mathrm{CaPP}$ showed highly decrease in atherogenic Index (AI) which were 2.55 and 3.10 respectively compared with positive control (9.28).

Tab. 4 showed the data of blood picture, it was noticed a significant increase in the hemoglobin among the tested

Tab. 5. Plasma ALT, AST and ALP activities (IU/L) in the experimental rats

\begin{tabular}{|c|c|c|c|}
\hline Treatments & $\operatorname{AST}(\mathrm{IU} / \mathrm{L})$ & $\operatorname{ALT}(\mathrm{IU} / \mathrm{L})$ & $\operatorname{ALP}(\mathrm{IU} / \mathrm{L})$ \\
\hline $\begin{array}{c}\text { G-1 } \\
\text { Negative Control }\end{array}$ & $28.4 \pm 2.32 \mathrm{~b}$ & $25.6 \pm 2.25 b$ & $91 \pm 4.81 \mathrm{~b}$ \\
\hline $\begin{array}{c}\text { G-2 } \\
\text { Positive Control }\end{array}$ & $93.1 \pm 6.42 \mathrm{a}$ & $86 \pm 4.04 \mathrm{a}$ & $183 \pm 4.25 \mathrm{a}$ \\
\hline $\begin{array}{c}\text { G-3 } \\
20 \% \mathrm{CaPP}\end{array}$ & $27.8 \pm 1.99 \mathrm{~b}$ & $24 \pm 2.23 \mathrm{~b}$ & $84.5 \pm 6.36 b$ \\
\hline $\begin{array}{c}\text { G-4 } \\
10 \% \mathrm{CaPP}\end{array}$ & $27.3 \pm 1.44 b$ & $24.8 \pm 2.28 b$ & $90.4 \pm 6.18 \mathrm{~b}$ \\
\hline
\end{tabular}

All values represented as mean + S.E. Means with different letters are significantly different $(p<0.05) .{ }^{*} \mathrm{CaPP}$ (carrot pomace powder) diet with $20 \% \mathrm{CaPP}(12.8 \pm 0.42)$ compared with negative control $(11.2 \pm 0.55)$ and positive control $(9.3 \pm 0.55)$ while the tested diet with level $10 \% \mathrm{CaPP}(11.8 \pm 0.4)$ was non significant with negative control. Also the red blood cells (RBCs) recorded no significant changes among the negative control (5.2 \pm 0.17$)$ and the group fed with $20 \% \mathrm{CaPP}$ $(5.1 \pm 0.15)$ and $10 \% \mathrm{CaPP}(4.7 \pm 0.16)$, while recorded a significant increase in $\mathrm{RBCs}$ compared with the positive control group (3.6 \pm 0.18$)$.

Tab. 4 also showed the Hematocrit Value (HCT \%). The CaPP groups with $20 \%$ \& $10 \%$ showed no significant change compared with negative control $(39.4 \pm 1.36$, $35.5 \pm 1.39$ and $36.9 \pm 2.02$ ) respectively, while they showed a significant increase around the positive control $(29.1 \pm 1.03)$.

The white blood cells (WBCs) count represented in the same table. The positive control $(3.3 \pm 0.24)$ and the CaPP group with $10 \%(4.9 \pm 0.99)$ showed significant decreases compared with negative control $(9.6 \pm 0.84)$. On the other hand the value of WBCs count of CaPP group with $20 \%(7.1 \pm 1.42)$ recorded non significant changes with negative control.

Tab. 5 illustrates the liver functions in the four groups. The aspartate aminotransferase (AST) showed a high significant decrease in group 3 and $4(27.8 \pm 1.99$ and $27.3 \pm 1.44)$ respectively compared with positive control (93.1 \pm 6.42 ), but there were non significant changes with the negative control group $(28.4 \pm 2.32)$. 
Furthermore, alanine aminotransferase (ALT) was represented in the obvious table. The tested groups recorded non significant changes with the negative control. Negative control was (25.6 \pm 2.25$)$, CaPP $20 \%$ was $(24 \pm 2.23)$ and CaPP $10 \%(24.8 \pm 2.28)$, on other hand there were a high significant decrease compared with the positive con-

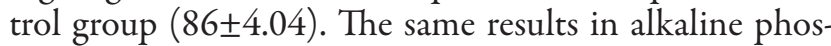
phatase (ALP) which showed a very highly significant decrease in the CaPP groups 10\% and 20\% (90.4 \pm 6.18 and $84.5 \pm 6.36)$ respectively compared with positive control

Tab. 6. Plasma urea and creatinine $(\mathrm{mg} / \mathrm{dL})$ of the experimental rats

\begin{tabular}{ccc}
\hline & $\begin{array}{c}\text { Urea } \\
(\mathrm{mg} / \mathrm{dL})\end{array}$ & $\begin{array}{c}\text { Creatinine } \\
(\mathrm{mg} / \mathrm{dL})\end{array}$ \\
\hline $\begin{array}{c}\text { Preatments } \\
\text { Negative Control } \\
\begin{array}{c}\text { G-2 } \\
\text { Positive Control } \\
\text { G-3 } \\
20 \% \text { CaPP } \\
\text { G-4 } \\
10 \% \text { CaPP }\end{array}\end{array}$ & $12.9 \pm 1.73 \mathrm{~b}$ & $1.2 \pm 0.07 \mathrm{a}$ \\
\hline
\end{tabular}

All values represented as mean + S.E. Means with different letters are significantly different $(p<0.05) .{ }^{*} \mathrm{CaPP}$ (carrot pomace powder)

Tab. 7. Plasma protein, albumin $(\mathrm{g} / \mathrm{dL})$ and plasma glucose $(\mathrm{mg} / \mathrm{dL})$ of the experimental rats

\begin{tabular}{|c|c|c|c|}
\hline Preatments & $\begin{array}{l}\text { Total protein } \\
\quad(\mathrm{g} / \mathrm{dL})\end{array}$ & $\begin{array}{l}\text { Albumin } \\
(\mathrm{g} / \mathrm{dL})\end{array}$ & $\begin{array}{l}\text { Glucose } \\
(\mathrm{mg} / \mathrm{dL})\end{array}$ \\
\hline $\begin{array}{c}\text { G-1 } \\
\text { Negative Control }\end{array}$ & $7 \pm 0.26 \mathrm{a}$ & $4 \pm 0.28 \mathrm{ab}$ & $87 \pm 6.67 b$ \\
\hline $\begin{array}{c}\text { G-2 } \\
\text { Positive Control }\end{array}$ & $4.2 \pm 0.28 \mathrm{c}$ & $2.5 \pm 0.24 \mathrm{c}$ & $105 \pm 3.95 \mathrm{a}$ \\
\hline $\begin{array}{c}\text { G-3 } \\
20 \% \text { CaPP }\end{array}$ & $7.5 \pm 0.2 \mathrm{a}$ & $4.3 \pm 0.17 \mathrm{a}$ & $87.5 \pm 3.52 b$ \\
\hline $\begin{array}{c}\text { G-4 } \\
10 \% \text { CaPP }\end{array}$ & $6 \pm 0.23 b$ & $3.5 \pm 0.18 b$ & $90.5 \pm 3.16 \mathrm{~b}$ \\
\hline
\end{tabular}

All values represented as mean + S.E. Means with different letters are significantly different $(p<0.05) .{ }^{*} \mathrm{CaPP}$ (carrot pomace powder)

Tab. 8. Relative organs weight ( $\mathrm{g}$ ) of the experimental rats

\begin{tabular}{ccccc}
\hline Organs & Liver & Heart & Kidney & Spleen \\
\hline $\begin{array}{c}\text { G- } 1 \\
\text { Negative Control }\end{array}$ & $9.1 \pm 0.27 \mathrm{~d}$ & $1.3 \pm 0.06$ a & $2.2 \pm 0.05 \mathrm{~b}$ & $1.1 \pm 0.05 \mathrm{a}$ \\
$\begin{array}{c}\text { G- } 2 \\
\text { Positive Control } \\
\begin{array}{c}\text { G-3 } \\
20 \% \text { CaPP }\end{array}\end{array}$ & $20.0 \pm 0.85 \mathrm{a}$ & $1.4 \pm 0.05 \mathrm{a}$ & $2.7 \pm 0.06 \mathrm{a}$ & $1.3 \pm 0.06 \mathrm{a}$ \\
$\begin{array}{c}\text { G- } 4 \\
10 \% \text { CaPP }\end{array}$ & $15.0 \pm 0.63 \mathrm{~b}$ & $1.4 \pm 0.05 \mathrm{a}$ & $2.5 \pm 0.07 \mathrm{a}$ & $1.2 \pm 0.05 \mathrm{a}$ \\
\hline
\end{tabular}

All values represented as mean + S.E.Means with different letters are significantly different $(p<0.05) .{ }^{*} \mathrm{CaPP}$ (carrot pomace powder)
$(183 \pm 4.25)$ but this value was non significant with negative control $(91 \pm 4.81)$.

Data in Tab. 6. represents the results of kidney function tests. Urea records an increase in CaPP with about 20\% level $(26.9 \pm 2.96)$ but this increase was non significant with the negative control group $(26.6 \pm 3.1)$, on the other side CaPP with $10 \%$ level $(19.5 \pm 2.92)$ was non significant with the positive control group $(12.9 \pm 1.73)$. Also the creatinine concentration showed in the same table recorded a significant decrease in $20 \% \mathrm{CaPP}$ group $(0.9 \pm 0.06) \mathrm{com}$ pared with the positive control $(1.2 \pm 0.07)$ while the $10 \%$ CaPP group $(1.2 \pm 0.05)$ showed non significant changes with the positive control.

The results presented in Tab. 7. indicate the hypercholesterolemia effects on blood glucose and plasma total protein and albumin. Total protein recorded a non significant changes between negative control $(7 \pm 0.26)$ and $20 \%$ CaPP group (7.5 \pm 0.2 ), while the $10 \%$ CaPP showed a significant decrease $(6 \pm 0.23)$ which was also significant compared with the positive control $(4.2 \pm 0.28)$ which recorded the lowest value.

Albumin was significantly decreased in 10\% CaPP group $(3.5 \pm 0.18)$ and positive control $(2.5 \pm 0.24)$ compared with the $20 \%$ CaPP group ( $4.3 \pm 0.17)$ which was non significant compared with the negative control $(4 \pm 0.28)$. In the same table, glucose records an increase in positive control group $(105 \pm 3.95)$, this increase in glucose level improved by supplementation with $20 \%$ CaPP $(87.5 \pm 3.52)$ and $10 \%$ CaPP $(90.5 \pm 3.16)$ this improve reached to the normal level of glucose in negative control group $(87 \pm 6.67)$.

Data in Tab. 8. illustrate the organs weight of the experimental rats, supplementations decreased the liver weight in CaPP with $10 \%(15.0 \pm 0.63)$ and the $20 \%$ level $(11.6 \pm 0.80)$ compared with positive control group (20.0 \pm 0.85$)$, on the other hand the negative control group recorded the lowest liver weight $(9.1 \pm 0.27)$. Kidney has non significant changes in weight between the $10 \% \mathrm{CaPP}$ group $(2.5 \pm 0.07)$ and positive control $(2.7 \pm 0.06)$, also the $20 \%$ CaPP group $(2.3 \pm 0.05)$ showed a value around the negative control $(2.2 \pm 0.05)$. Finally, heart and spleen weights showed non significant changes in all groups.

\section{Discussion}

Chemical composition of CaPP was shown that Capp is rich in fibers (11.8\%) dry weight, results was agree with Bao and Chang (1994) who found that the carrot pomace is rich in fiber more than carrot peels and more that some agriculture by-products such as pear, orange, peach. Also these results are in the same line with Chau et al. (2004a) who found that carrot pomace was rich in dietary fiber and low in protein whereas, the values reported by Holland $e t$ al. (1991) for most of these parameters are different i.e. moisture $(88.8 \%)$, protein $(0.7 \%)$, fat $(0.5 \%)$, crude fiber (2.4\%). 
12

The increase in BWG, FI and FER for positive control which fed on hypercholesterolemic diet may be due to the presence of animal fat and cholesterol used to increase feeding. Also results revealed that the reduction in BWG of the rats fed on diet containing 20\% CaPP indicate muscle tissue wasting this decrease may due to high content of fiber, these results were agreed with Parveen et al. (2000) who reported that the fiber content of diet reduce calories and losses weight.

However Chau et al. (2004b) was on an opposite side, they found that consumption of water-insoluble fiber rich fraction didn't affect the weights of hamsters. Also Nicolle et al. (2003) were on contrary line with our study who found no significant changes on body weight gain and food intake in the groups feed on carrot diet with the control group.

The addition of carrot in the diet with 10,20\% concentrations lead to decrease in total lipid, total cholesterol, triglycerides and LDL-C but resulting increase of HDLC. Our data was in the same line with Nicolle et al. (2003) who found carrot consumption exerts a moderate lowering cholesterol effect (12\% decreases). A significant $11 \%$ reduction of cholesterol has been observed in human subjects by Robertson et al. (1979).

Hsu et al. (2006) recorded significant decrease in concentration of serum triglyceride, serum total cholesterol of hamsters fed on diet containing insoluble fiber-rich fractions prepared from carrot pomace. Whereas an absence of effect was reported by Wisker et al. (1994).

The improvement in lipid profile of blood could be referred to a multi factors besides on the role of amino acids of protein, dietary fibers and antioxidants may play a good part in this action. Beneficial treatment of CaPP showed that the dietary fibers are having the potential to lower the levels of total cholesterol and LDL-c in blood. Absorption of bile salts by soluble dietary fiber (SDF) results in changes in cholesterol metabolism, loss of cholesterol, unavailability of bile salts in the intestine for micelle formation, which inhibits lipid fractions absorption, increased fecal bulk dilutes bile acids in the lower intestinal tract, and short chain fatty acids produced especially the propionate, which has been proposed to inhibit hepatic cholesterol synthesis (Tharanathan and Mahadevamma, 2003).

The improvement in blood picture data was noticed especially in hemoglobin which recorded a significant increase in 20\% CaPP than control group also hematocrite was in significant increase in 10\%, 20\% CaPP compared with positive control, this increase in blood picture may due to the high presence of iron. These data were corresponding with Sharma et al. (2012) who found that carrot are a good source of minerals like $\mathrm{Ca}, \mathrm{P}, \mathrm{Fe}$ and $\mathrm{Mg}$. Also Gopalan et al. (1991) reported the chemical constituents of carrot as moisture $(86 \%)$, protein $(0.9 \%)$, crude fiber $(1.2 \%)$ and $\mathrm{Fe}(2.2 \mathrm{mg} / 100 \mathrm{~g}), \mathrm{Ca}(80 \mathrm{mg} / 100 \mathrm{~g})$ and $\mathrm{P}(53$ $\mathrm{mg} / 100 \mathrm{~g})$.
The previous results indicated that the rats fed on hypercholesterolemic diet showed increased liver enzymes (AST, ALT and Alkaline phosphatase). The liver is a central organ for many physiological and biochemical process necessary for maintenance of life (Souba and Wilmore, 1983). Morphological alterations that occur in the liver affect many metabolic processes in the organism. Peroxide formation induced by hypercholesterolemia (Sudhahar $e t$ al., 2007) result in the release of some enzymes by interacting with cellular structure and function. Thus, the serum activities of cellular enzymes such as transaminases, alkaline phosphatase, and lactate dehydrogenase do increase. With the increase in cellular membrane permeability, intracellular fluid transfers onto intercellular space, resulting in muscle and liver cell degeneration.

Rats fed on 10 and 20\% CaPP supplemented to hypercholesterolemic diet showed improved liver functions. AST and ALT levels act as indicators of liver functions, hence, restoration of normal levels of these enzymes indicates normal functions of liver. The reduction of AST and ALT close to their normal levels due to consumption of CaPP (Quanhong et al., 2005). The present study also revealed that the ALP activity was increased when the liver functions abnormally (Rashad and Moharib, 2008), thus the study of liver ALP was done in the present study to find out the effect of these dietary fiber $(\mathrm{CaPP})$ on liver ALP.

Results showed that CaPP with 10 and $20 \%$ had a lowering effect on the activity of ALP in serum of hypercholesterolemic rats compared to the positive control, but this decrease was not significant with the negative control group. This effect is mainly related to the presence of natural soluble and insoluble dietary fiber (Rashad and Moharib, 2003).

The result of the present study also declared that CaPP especially at $20 \%$ level has a significant improvement effect on the kidney functions represented in urea and creatinine. This could be explained as consumption of food rich in dietary fibers stimulates the extrarenal route of nitrogen excretion. Younes et al. (1998) found that indigestible carbohydrate/dietary fibers increased cecal weight and cecal blood flow, leading to accelerated diffusion of blood urea into the cecal lumen (by threefold), urea lysis to ammonia and protein synthesis by the microflora, and increased fecal excretion of nitrogen. Thus, reduce the role of kidney in the excretion of nitrogen and reduce blood urea concentration.

Total protein and albumin were markedly increased with addition of $10 \%, 20 \%$ CaPP especially with $20 \%$, these results were on a opposite side to Eggum (1992) who reported that dietary fiber had a negative influence on digestion and assimilation of proteins. Also results show a markedly decrease of glucose on hypercolesterolemic rats fed on 10 and 20\% CaPP. These results were confirmed by Chau et al. (2004a) who found that fiber has functional properties and in vitro hypoglycemic effects. Rodríguez 
et al. (2006) declared that glucose of diabetic patients decreased by having diets rich in fiber. These results given are in a good agreement with Singh et al. (2005) who found that feeding of PoPP at $5 \%$ and $10 \%$ to diabetic rats signicantly decreased their blood glucose level.

It could be noticed from previous results that hypercholesterolemia increased organs weight especially liver and kidney compared with negative control, while their spleen and heart had no significant changes in their weight. However, $10 \%$ and $20 \% \mathrm{CaPP}$ supplemented to hypercholesterolemic treated groups had a significantly decreased in liver and kidney weights.

\section{Conclusions}

Finally the present results clearly refer to possibility using carrot pomace powder as hypocholesterolemic agent. In addition, $\mathrm{CaPP}$ also serves to improve the lipid profile (cholesterol, total lipid, triglycerides, LDL-C and HDLC) and blood picture and to reduce the blood glucose level in hypercholesterolemic rats and could use in obese people for body loss.

\section{References}

Allain CC, Poon LS, Chan CS, Richmoud W, Fu PC (1974). Enzymatic determination of total serum cholesterol. Clin Chem 20(4):470-475.

Anderson JW, Baird P, Davis RH Jr, Ferreri S, Knudtson M, Koraym A, Waters V, Williams CL (2009). Health benefits of dietary fiber. Nutr Rev 67(2):188-205.

AOAC (2000). Method of analysis. Association of Official Agriculture Chemists. $17^{\text {th }}$ ed, Washington D.C., USA.

Bao B, Chang KC (1994). Carrot pulp chemical composition, colour, and water-holding capacity as affected by blanching. J Food Sci 59(6):1159-1161.

Burstein M (1970). A fully enzymatic colorimetric determination of HDL cholesterol in the serum. Lipid Res 11:583 595.

Campbell TW (1995). Avian hematology and cytology, $2^{\text {nd }}$ ed. Iowa State University Press, Ames, Iowa, 3-19 p.

Chandalia M, Garg A, Lutjohann D, von Bergmann K, Grundy SM, Brinkley LJ (2000). Beneficial effects of high dietary fiber intake in patients with type 2 diabetes mellitus. N Engl J Med 342(19):1392-1398.

Chantaro P, Devahastin S, Chiewchan N (2008). Production of antioxidant high dietary fiber powder from carrot peels. Food Sci Technol 41(10):1987-1994.

Chau CF, Chen CH, Wang YT (2004b). Effects of a novel pomace fiber on lipid and cholesterol metabolism in the hamster. Nutrit Res 24:337-345.

Chau CF, Chen CH, Lee MH, Chau CF, Chen CH, Lee MH (2004a). Comparison of the characteristics, functional properties and in vitro hypoglycemic effects of various car- rot insoluble fiber-rich fractions. LWT-Food Sci Technol 37(2):155-160.

Doumas BT, Peters T Jr (1997). Serum and urine albumin: a progress report on their measurement and clinical significance. Clin Chem Acta 258(1):3-20.

Eggum BO (1992). The influence of dietary fibre on protein digestion and utilisation, 153-165p. In: Schweizer TF, Edwards CA (Eds.). Dietary Fibre-A Component of Food. Nutritional Function in Health and Disease, Springer-Verlag, London.

Faulkner NR, King JW (1976). Fundamental of clinical chemistry (2 ${ }^{\text {nd }}$ ed.) Tietz, Sannders Philadelphia, 994-998 p.

Fisher RA (1970). Statistical method for research workers Edinburgh ed. 14. Oliver and Boyed, $140 \mathrm{p}$.

Fossati P, Prencipe L (1982). The determination of triglyceride using enzymatic methods. Clin Chem 28:2077-2080.

Fukushima M, Takayama Y, Habaguchi T, Nakano M (1997). Comparative hypocholesterolemic effects of capybara ( $H y$ drochoerus hydrochaeris dabbenei) oil, horse oil and sardine oil in cholesterolfed rats. Lipid 32(4):391-395.

Gerschenson LN, Rojas AML, de Escalada Pla M, Fissore E (2009). Functional properties of dietaryfibre isolated from Cucurbita moschata Duchesne ex Poiret through different extraction procedures, 359-370 p. In: Govil JN, Singh VK (Eds.). Recent Progress in Medicinal Plants. Volume 24 Standardization of herbal/ayurvedic formulations. Texas: Studium Press LLC.

Gopalan C, Rama Sastri BV, Balasubramanian SC (1991). Nutritive value of Indian foods. National institute of Nutrition, ICMR, Hyderabad.

Graham I, Atar D, Borch-Johnsen K (2007). European guidelines on cardiovascular disease prevention in clinical practice: executive summary. Eur Heart J 28:2375-2414.

Henry RJ (1976). Clinical chemistry, Hoeber, NY, 413 p.

Holland B, Unwin ID, Buss DH (1991). Vegetables, Herbs and Spices. Fifth supplement to McCance and Widdowson's. The Composition of Foods, Royal Society of Chemistry, Cambridge, London.

Hsu PK, Chien PJ, Chen CH, Chau CF (2006). Carrot insoluble fiber-rich fraction lowers lipid and cholesterol absorption in hamsters. LWT-Food Sci Technol 39(4):338-343.

Ingelsson E, Schaefer EJ, Contois JH, McNamara JR, Sullivan L, Keyes MJ, Pencina MJ, Schoonmaker C, Wilson PW, D'Agostino RB, Vasan RS (2007). Clinical utility of different lipid measures for prediction of coronary heart disease in men and women. JAMA 298(7):776-85.

International Committee for Standardization in Haematology. (1967). Recommendations for haemoglobinometry in human blood. Brit J Haemat 13(4):71-75.

Knight JA, Anderson SJ, Rawle JM (1972). Chemical bases of the sulfo-phosphovanillin reaction for estimating serum total lipid. Clin Chem 18(3):199-202.

Lee R, Niemann D (1996). Nutritional Assessment $2^{\text {nd }}$ ed Mos- 
14 by Missou USA.

Levy AL (1981). A fully enzymatic colourimetric determination of LDL-cholesterol in the serum. Clin Chem 27(5):653662.

Natt MP, Herrick CA (1952). A new blood count diluent for counting erythrocytes and leukocytes of the chicken. Poult Sci 31:735-738.

Nawirska A, Uklańska C (2008). Waste products from fruit and vegetable processing as potential sources for food enrichment in dietary fibre. Acta Sci Pol Technol Aliment 7(2):3542.

Nicolle C, Cardinault N, Aprikian O, Busserolles J, Grolier P, Rock E, Demigné C, Mazur A, Scalbert A, Amouroux P, Rémésy C (2003). Effect of carrot intake on cholesterol metabolism and on antioxidant status in cholesterol-fed rat. Eur J Nutr 42(5):254-61.

Parveen N, Akhtar MS, Abbas N, Abid AR (2000). Effects of carrot residue fibre on body weight gain and serum lipid fractions. Int J Agri Biol 2:125-128.

Patton CJ, Crouch SR (1977). Spectrophotmetric and kinetics investigations of the Berthelot reaction for the determination of ammonia. Anal Chem 49:464-469.

Quanhong L, Caili F, Yukui R, Guanghui H, Tongyi C (2005). Effects of protein-bound polysaccharide isolated from pumpkin on insulin in diabetic rats. Plant Foods Hum Nutr 60(1):13-16.

Rashad MM, Moharib SA (2003). Effect of type and level of dietary fiber supplements in rats. Grasas y Aceites 54:277284.

Rashad MM, Moharib SA (2008). Studies of the effect of some plant leaf fibers on the key liver enzymes intermediate carbohydrate and lipid metabolism in rats. Adv Food Sci 1:1-8.

Rec G (1972). Optimised standard colorimetric methods. J Clin Chem Clin Biochem10:182-185.

Reitman S, Frankel S (1957). A colourimetric method for the determination of serum glutamic oxaloacetic and glutamic pyruvic transaminases. Am J Clin Path 28(56):56-62.

Robertson J, Brydon WG, Tadesse K, Wenham P, Walls A, Eastwood MA (1979). The effect of raw carrot on serum lipid and colon function. Am J Clin Nutr 32:1889-1892.

Rodríguez R, Jiménez A, Fernández-Bolaños J, Guillén R, Heredia A (2006). Dietary fibre from vegetable products as source of functional ingredients. Trends Food Sci Technol $17: 3-15$
SPSS (1999). Statistical Package for the Social Sciences, version 10, SPSS, Inc., Chicago, Illinois.

Schieber A, Stintzing FC, Carle R (2001). By-products of plant food processing as a source of functional compounds-recent developments. Trends Food Sci Technol 12:401-413.

Schneeman BO (2007). Dietary fiber and gastrointestinal function, 168-176 p. In: Mccleary BV, Prosky L (Eds.). Advanced Dietary Fiber Technology, Black Well Science, Oxford.

Sharma KD, Karki S, Thakur NS, Attri S (2012). Chemical composition, functional properties and processing of carrota review. J Food Sci Technol 49(1):22-32.

Singh N, Kamath V, Rajini PS (2005). Protective effect of potato peel powder in ameliorating oxidative stress in streptozotocin diabetic rats. Plant Foods Human Nutr 60(2):49-54.

Souba WW, Wilmore DW (1983). Postoperative alteration of arteriovenous exchange of amino acids across the gastrointestinal tract. Surgery 94(2):342-350.

Sudhahar V, Kumar SA, Sudharsan PT, Varalakshmi P (2007). Protective effect of lupeol and its ester on cardiac abnormalities in experimental hypercholesterolemia. Vascul Pharmacol 46:412-418

Tharanathan RN, Mahadevamma S (2003). Grain legumes-a boon to human nutrition. Trends Food Sci Technol 14:507518.

Trinder P (1969). Determination of blood glucose using an oxidation peroxidase system with a non carsinogenic chromogene. Ann Clin Biochem 6:24-26.

Van Way CW, Ireton-Jones CS (2004). Nutrition Secrets. $2^{\text {nd }}$ Edition, Hanley and Belfus Inc., Philadelphia. Pennsylvania. $284 \mathrm{p}$.

Waller RA, Duncan DB (1969). Aboys rule for symmetric multiple comparison problem. An State Assoc J 65:1485-1503.

Wisker E, Schweizer TF, Daniel M, Feldheim W (1994). Fibremediated physiological effects of raw and processed carrots in humans. J Nutr 72(4):579-599.

Younes H, Garleb KA, Behr SR, Demigne C, Remesy C (1998). Dietary fiber stimulates the extrarenal route of nitrogen excretion in partially nephrectomized rats. J Nutr Biochem 9:613-620. 